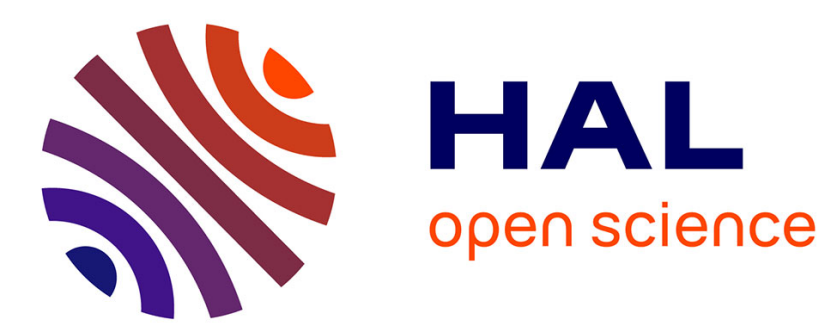

\title{
EXPERIMENTAL K X-RAY RELATIVE TRANSITION PROBABILITIES
}

\author{
F.M. Marqués, M. Martins, Jorge Ferreira
}

\section{To cite this version:}

F.M. Marqués, M. Martins, Jorge Ferreira. EXPERIMENTAL K X-RAY RELATIVE TRANSITION PROBABILITIES. Journal de Physique Colloques, 1987, 48 (C9), pp.C9-601-C9-604. 10.1051/jphyscol:1987999 . jpa-00227420

\section{HAL Id: jpa-00227420 https://hal.science/jpa-00227420}

Submitted on 1 Jan 1987

HAL is a multi-disciplinary open access archive for the deposit and dissemination of scientific research documents, whether they are published or not. The documents may come from teaching and research institutions in France or abroad, or from public or private research centers.
L'archive ouverte pluridisciplinaire HAL, est destinée au dépôt et à la diffusion de documents scientifiques de niveau recherche, publiés ou non, émanant des établissements d'enseignement et de recherche français ou étrangers, des laboratoires publics ou privés. 


\title{
EXPERIMENTAL K X-RAY RELATIVE TRANSITION PROBABILITIES
}

\author{
M.I. MARQUES, M.C. MARTINS and J.G. FERREIRA \\ Departamento de Fisica e Centro de Fisica, Atomica da \\ Universidade de Lisboa, Avenida Pr. Gama Pinto 2 , \\ P-1699 Lisboa Codex, Portugal
}

\section{Abstract}

Des determinations de rapports d'intensités de raies du spectre XK sont en cours pour des éléments de $47<\mathrm{Z}<81$. Résultats obtenus pour $\mathrm{K} \alpha_{2} / \mathrm{K} \alpha_{1}$ sont présentés dans ce travail.

Measurements of $\mathrm{K} X$-ray relative intensities are under way in our group for elements with $47 \leq \mathrm{Z} \leq 81 . \quad \mathrm{Ko}{ }_{2} / \mathrm{Ko} \alpha_{1}$ values are presented in this work.

Although extensive measurements of relative intensities of the major $K \mathrm{X}$-ray groups have been performed by several authors, accurate measurements of the relative $\mathrm{K} X$-ray transition probabilities are scarce.

Measurements of radiative transition probabilities $\mathrm{K} \rightarrow \mathrm{L}_{2} / \mathrm{K} \rightarrow \mathrm{L}_{3}, \mathrm{~K} \rightarrow \mathrm{N} / \mathrm{K} \rightarrow \mathrm{M}$, $\mathrm{K} \rightarrow \mathrm{M}_{2} / \mathrm{K} \rightarrow \mathrm{M}_{3}, \quad \mathrm{~K} \rightarrow \mathrm{M} / \mathrm{K} \rightarrow \mathrm{L}$ in the atomic number region $47 \leq \mathrm{Z} \leq 8 \mathrm{I}$ are under way in our group; results concerning the $\mathrm{K} \rightarrow \mathrm{L} 2 / \mathrm{K} \rightarrow \mathrm{L} 3$ ratio for 9 elements are presented.

$\mathrm{X}$-ray spectra are produced following radioactive ( $\beta^{-}$or e.c.) decay. The detector is an ORTEC GeHP, $10 \mathrm{~mm}$ in diameter and $7 \mathrm{~mm}$ deep, fitted with $0.125 \mathrm{~mm}$ Be window and having a resolution of $195 \mathrm{eV}$ (FWHM) at $6.4 \mathrm{keV}$.

$$
\text { Solutions of }{ }^{125} \mathrm{Sb},{ }^{133} \mathrm{Ba},{ }^{137} \mathrm{Cs},{ }^{153} \mathrm{Gd},{ }^{169} \mathrm{Yb},{ }^{170} \mathrm{Tm},{ }^{181} \mathrm{Hf},{ }^{195} \mathrm{Au},{ }^{203} \mathrm{Hg} \text {, }
$$

${ }^{241} \mathrm{Am},{ }^{57} \mathrm{Co}$ and ${ }^{109} \mathrm{Cd}$ were obtained from Amersham. Sources were prepared by evaporating a droplet of solution on mylar film $6 \mu \mathrm{m}$ of thickness and were covered with the same mylar.

The efficiency calibration of the source-detector system in the region 14-130 $\mathrm{keV}$ was computed from the well-known intensity ratios of $x$ and $\gamma$ rays in ${ }^{241} \mathrm{Am}$, $57 \mathrm{Co},{ }^{109} \mathrm{Cd}$ and ${ }^{133} \mathrm{Ba}$ spectra.

The two $K \alpha$ components, $K \rightarrow L_{2}$ and $K \rightarrow L_{3}$, overlap for all the elements of this work. The peak areas were obtained by fitting the Ka spectra with a linear background, $\mathrm{B}(\mathrm{x})$, and a function

$$
\mathrm{F}(\mathrm{x})=\mathrm{G}(\mathrm{x})+\mathrm{D}(\mathrm{x})+\mathrm{S}(\mathrm{x})
$$

per each $X$-ray component. $G(x), D(x)$ and $S(x)$ represent the gaussian, tailing and step functions, respectively, with the expressions given by Philips e Marlow [1]. $\mathrm{G}(\mathrm{x})$ has three free parameters, the height, $\mathrm{H}_{\mathrm{C}}$, the line width, $\Gamma$, and the centroid position. For $\mathrm{D}(\mathrm{x})$ the parameters are the height, $H_{D}$, and the slope, $\beta$.

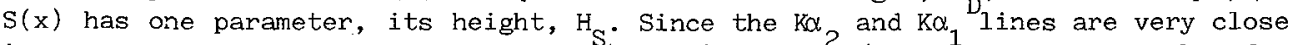
in energy we admit that the ratios $H_{D} / H_{G}, B / \Gamma_{G}$ and $\mathrm{H}_{S^{\prime}}{ }^{\prime} H_{G}$ have the same value for both lines. Initial values for $H_{D} / H_{G}$ and $\beta / \Gamma_{G}{ }_{\text {were }}$ taken from $\gamma$-ray fittings, with the total function, $F(x)+B(x)$, in the same energy region. The Ko spectra and the result of the fit with the function $F(x)$ for $Z=55$ and 81 are presented in figures 1 and 2 , respectively.

As $Z$ increases the natural line width, $\Gamma$, becomes relatively more important $\left(\Gamma_{G} / \Gamma \simeq 20\right.$ for $Z=52$ and $\simeq 6$ for $\left.Z=80\right)$. To account for this, we replaced, for 


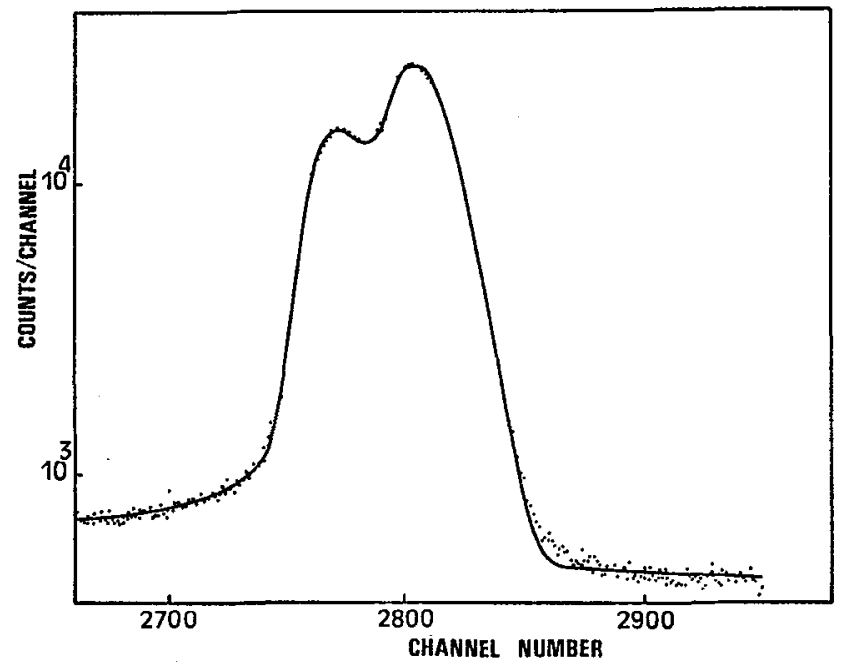

Fig. 1 Fit of $\mathrm{Cs} \mathrm{K} \alpha$ spectrum with one $F(x)$ function (1) per each component added to a linear background.

Although the convolution of $\mathrm{F}(\mathrm{x})$ or, at least, $\mathrm{G}(\mathrm{x})$, with the Lorentzian is an important step in the evaluation of the natural width [2], it doesn't seem to affect the value of $\mathrm{K} \alpha_{2} / \mathrm{K \alpha}_{1}$ in a significant way.

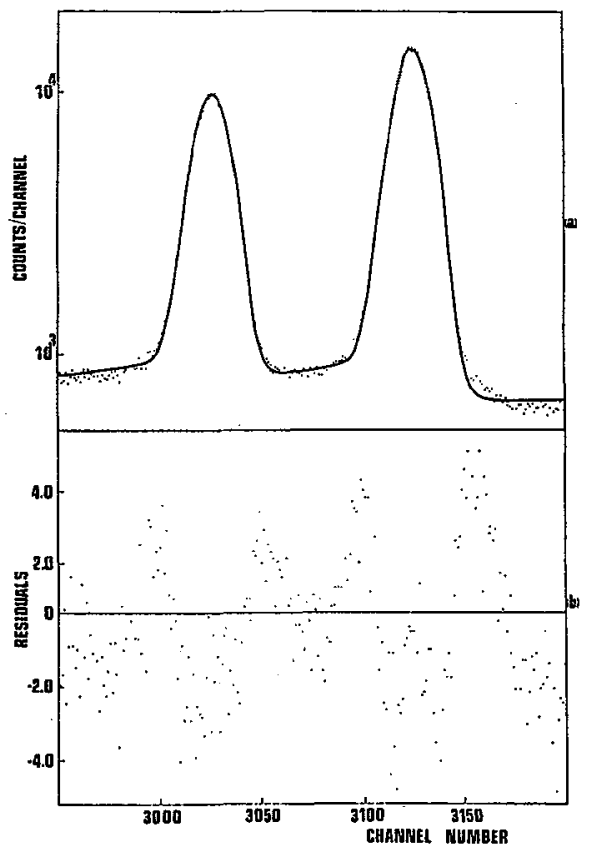

Fig.2(a) Fit of T1 Ko spectrum with one $\mathrm{F}(\mathrm{x})$ function (I) per each component added to a linear background.

(b) The residuals are given as multiples of one standard deviation.

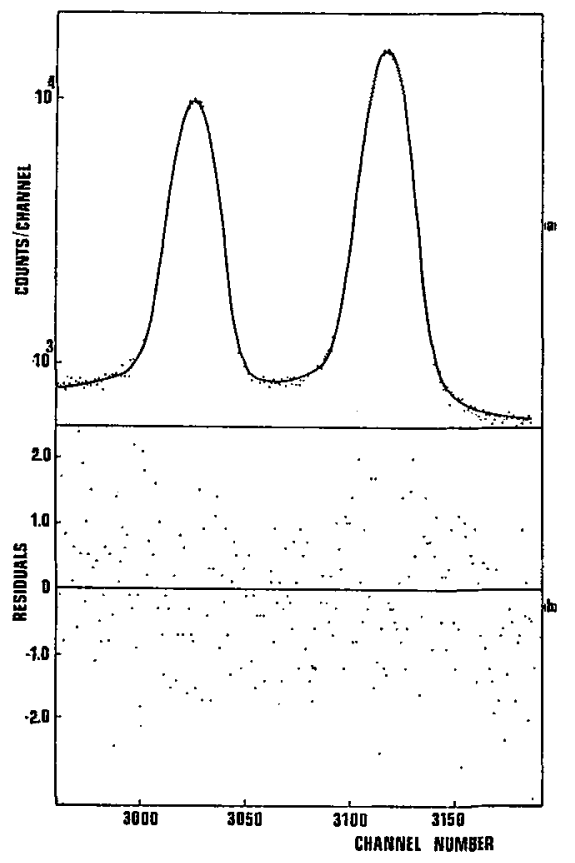

Fig.3(a)(b) The same of fig.2 with the Voigt function instead of the gaussian in the $F(x)$ Function. 
high $Z$, the function $G(x)$ by a Voigt function. This introduced an improvement in the fit. In fig, 2 and fig, 3 we show, for the $T l$ spectrum, the results of the fittings with the two functions. The residuals are also presented.

The analysis of at least three spectra for each element was achieved with the $F(x)$ function. The results for the $K \theta_{2} / K \alpha_{1}$ ratio are listed in table $I$ and are plotted in fig.4 together with theoretical values of Scofield and other experimental results obtained with fluorescence or radioactive decays.

Table I

\begin{tabular}{|cc|cc|cc|}
\hline$z$ & $\mathrm{~K} \alpha_{2} / \mathrm{K} \alpha_{1}$ & 7 & $\mathrm{~K} \alpha_{2} / \mathrm{K} \alpha_{1}$ & $\mathrm{z}$ & $\mathrm{K} \alpha_{2} / \mathrm{K} \alpha_{1}$ \\
\hline 52 & $0.509+0.010$ & 63 & $0.552+0.009$ & 73 & $0.571+0.009$ \\
55 & $0.522+0.009$ & 69 & $0.551+0.009$ & 78 & $0.577+0.009$ \\
56 & $0.541+0.009$ & 70 & $0.560+0.009$ & 81 & $0.600+0.009$ \\
\hline
\end{tabular}

The contributions for the estimated error are: statistics $(<0.2 \%)$, efficiency correction $(0.1-0.3 \%)$ and fit uncertainty.

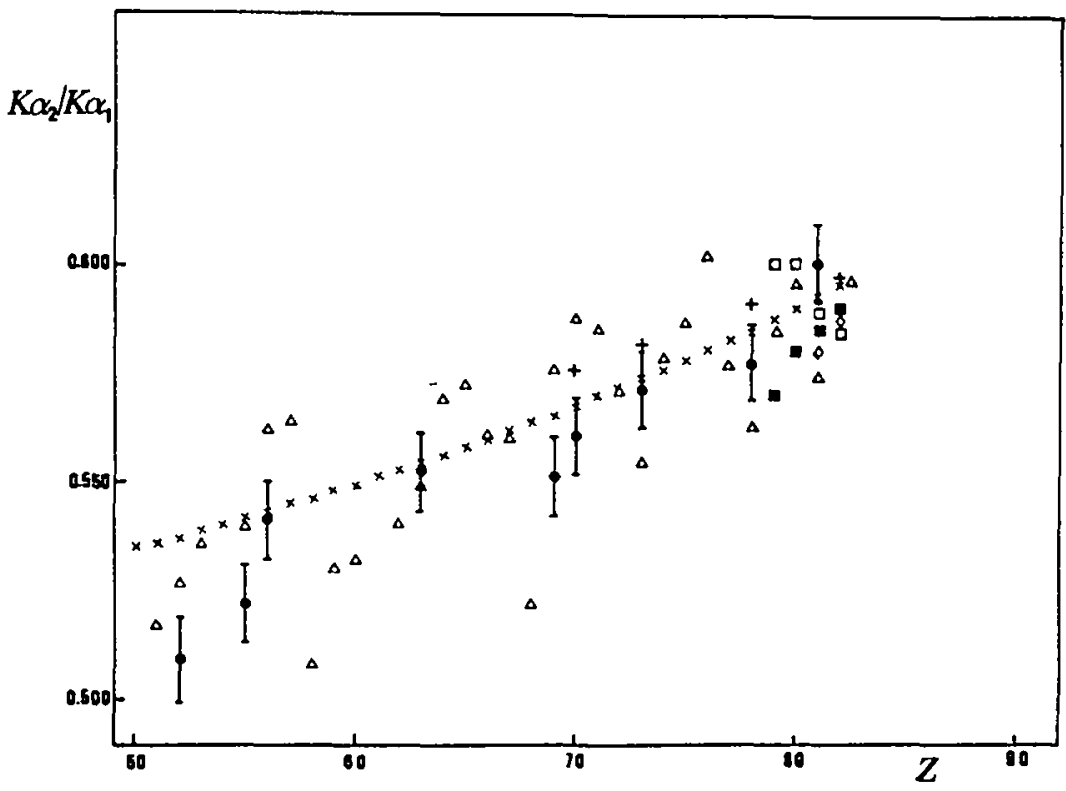

Fig. 4 Comparison of experimental values of $K \alpha_{2} / K \alpha_{\text {and }}$ ane theoretical predictions of Scofield $x-[7] ;+-[2], \Delta-[3], \square-[4], \square-[5], 0-[6], 0-$ present work.

For $Z<70$ the only previous experimental values (fig.4) were those of Nelson et al. [3] with errors of $5 \%$. For $z \geq 70$, more information is available, but in many cases errors are large [3] [4] [5] [6]. If we compare our values with those predicted by Scofield we conclude that they agree within the experimental errors for $56<\mathrm{Z} \leq 81$; for $\mathrm{Z}=52$ and 55 our values are lower than the theoretical ones by 5 to $4 \%$. 


\section{References}

[1] PHILLIPS (G.W.), MARLOW (K.), Nuclear Instruments and Methods, 1976, 137, 525.

[2] CAMPBELl (J.L.), SCHUlte (G.W.), Phys. Rev. A, 1980, 22, 609.

[3] Nelson (G.C.), SAUNDERS (B.G.), Phys. Rev., 1969, 188, 108.

[4] VYLOV (T.), DZHELEPOV (B.S.), IVANOV (R.B.), MIKHAILOVA (M.A.), SERGEEV (V.o.), Izv, Akad. Nauk SSSR. Ser. Fiz., 1972, 36, 2136.

[5] PINHO (A.G.), Phys. Rev. A, 1971, 3, 905.

[6] HANSEN (J.S.), FREUND (H.U.), FINK (R.W.), Nuclear Phys., 1970, A 142, 604.

[7] SCOFIELD (J.H.), At. Data and Nuclear Data Tables, 1974, 14, 121.

SCOFIELD (J.H.), Phys. Rev. A, 1974, 9, 1041. 